JURNAL DAKWAH DAN KOMUNIKASI

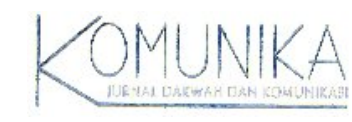

\title{
Islam dan Globalisasi: Sebuah Pandangan tentang Universalitas Islam
}

\author{
Khusnul Khotimah"
}

"Penulis adalah Magister Agama (M.Ag.), dosen tetap Junusan Komunikasi (Dakwah) STAIN Pumokerto.

\begin{abstract}
Globalization is a historical fact that has significant influence on societys life system. This condition has to face with wise reaction. Islam as religion that hove universal and global order, certainly have role on solving globalization problem. Its clear from its universality, Islam can have significant role to shape global community. Islamic universalism can be seen from several manifestations, e/g: cosmopolitan cultural teaching, science development, holistic social order and complete values. From this, Islam universality is able to face economic, education, culture, technology and other problems. Keywords: Globalization, Islamic universality, Cosmopolitan culture.
\end{abstract}

\section{PENDAHULUAN}

Isu seputar globalisasi mulai marak sekitar dekade 1990-an, pada masa ini sering disebut sebagai zaman globalisasi atau the age of globalization. Ramainya diskursus seputar globalisasi pada dekade ini tidak lepas dari booming ekonomi yang melanda dunia. Era pasar bebas (free trade) yang tidak lagi dibatasi oleh sekat-sekat geografi, budaya, dan ideologi politik sebuah negara, seolah sudah menjadi suatu kepastian yang harus terjadi. Meski berangkat dari persoalan ekonomi, namun globalisasi tidak hanya didominasi oleh masalah ekonomi saja, tetapi juga berkaitan dengan persoalan-persoalan lain seperti sosial, budaya, agama, politik, pendidikan, dan lain sebagainya.

Sebagaimana diungkapkan oleh Uskup Agung Wulsttan, dalam khutbahnya di York pada tahun 1014, "Dunia bergerak dengan cepat dan tengah mendekati titik nadirnya”. Mudah dibayangkan bahwa perasaan yang sama juga diungkapkan pada zaman sekarang. Apakah harapan dan kegelisahan di setiap periode hanyalah salinan dari masa-masa sebelumnya? Apakah dunia tempat kita hidup di akhir abad ke-20 ini sungguh berbeda dengan waktu-waktu sebelumnya?' Banyak kegelisahan yang muncul menyertai setiap perubahan yang terjadi, terlebih ketika globalisasi dianggapap telah menjadi 'momok' yang dirasa sangat menakutkan karena pengaruhnya luar biasa dalam merombak struktur kehidupan manusia, baik secara personal maupun dalam kehidupan kolektif masyarakat, berbangsa, dan bernegara.

Akan tetapi, menyikapi dengan penuh 'ketakutan' atas fenomena yang tidak bisa dihindari, tentu bukan sesuatu yang diharapkan. Globalisasi merupakan keharusan sejarah yang mesti disikapi dengan arif, terlebih bagi umat Islam yang memiliki tatanan ajaran global yang sangat luhur dan tetap relevan dengan perkembangan zaman. Globalisasi, dalam pemaknaan perubahan, merupakan ketentuan Illahi (natural law) yang mau tidak mau pasti akan terjadi. Filosof Heiraklitus pernah menyatakan bahwa "semua yang ada di dunia ini akan berubah, tidak ada yang abadi, kecuali perubahan itu sendiri."

Proses globalisasi sebenarnya bukanlah suatu fenomena baru dalam sejarah peradaban dunia. Ciri khas globalisasi adalah semangat keterbukaan dan kerelaan untuk menerima pengaruh budaya lain. Hal ini sebagaimana dalam sejarah Romawi, yang golongan tertakluk pada masa kekaisaran Romawi menuntut hak yang sama sebagaimana dimiliki oleh penakluk. Mereka menginginkan hak untuk memilih perwakilan dan perlindungan dari segi undang-undang yang serupa dengan rakyat Romawi, dengan argumen "Civis Romamus Sum”, aku ini rakyat Romawi. Atas kesadaran ini, Kaisar Marcus Aurelius, yang terkenal karena pemikirannya yang cukup modern dalam bukunya "Meditations", membuka kerakyatan Romawi kepada semua etnik dan bangsa dari Dubrovnik di Balkan, hingga ke Colonia di Utara Rhine sampai ke York sampai 


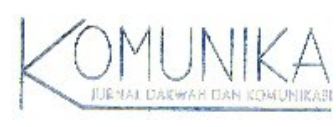

di Pulau Britain. Kejayaan Romawi, dalam sepuluh abad seterusnya, berlandaskan sikap keterbukaan golongan pemerintah terhadap konsep globalisasi. Selanjutnya, globalisasi Romawi membawa kepada penerimaan budaya dominan masyarakat Itali Tengah. Bahasa Roma dipergunakan hingga ke penghujung benua Eropa. Dalam bahasa, perkataan-perkataan Romawi mulai dipergunakan di Persia dan Semenanjung Arab. ${ }^{3}$

Sebagai sebuah keniscayaan sejarah, lalu bagaimana pandangan Islam sebagai agama dakwah menghadapi globalisasi? Tulisan ini tidak bermaksud menyejajarkan antara Islam dan globalisasi sebagai dua terma yang saling bertentangan, tetapi lebih menitikberatkan pada Islam sebagai agama dakwah global, yang memiliki pemahaman universal dalam menghadapai globalisasi.

\section{DISKURSUS GLOBALISASI}

Globalisasi merupakan diskursus yang banyak mengundang perdebatan masyarakat dunia, baik yang setuju (pro) maupun yang anti (kontra). Mereka yang setuju pada umumnya berangkat dari pemahaman bahwa globalisasi adalah suatu keniscayaan sejarah yang harus diterima dengan lapang dada. Sementara itu, yang anti-globalisasi melihat pada akibat yang timbul dari globalisasi itu sendiri, terutama pengaruhnya yang destruktif bagi lingkungan hidup.

Globalisasi sendiri dalam percaturan masyarakat dunia telah menjadi terma yang sangat populer dan sering digunakan untuk menggambarkan situasi dunia yang sedang berkembang. Hal ini pernah dinyatakan secara gamblang oleh Alvin dan Heidi Toffler:

"Few words are more loosely throun about today than the term 'global. Ecology is said to be a 'global' problem. The media are said creating a 'global rillage. Companies proudly announce that they are 'globalizing'. Economists speak of 'global' growth or recession. And the politician, UNofficial, or media punditdoesn'texists who isn'tprepared to lectureus about the global system?"4

Secara prinsip, globalisasi merupakan sebuah proses 'penyatuan' dunia, yang secara perlahan, tetapi pasti mulai menghilangkan sekat-sekat negara dan bangsa. Proses penyatuan ini melibatkan manusia, informasi, perdagangan, dan modal. Derasnya arus informasi yang masuk lintas benua telah menghilangkan halangan-halangan yang diakibatkan oleh batas-batas dimensi ruang dan waktu. Oleh karenanya, suatu peristiwa yang terjadi di belahan bumi akan segera bisa diketahui di belahan bumilainnya.

Ada banyak indikasi yang menunjukkan telah berlangsungnya proses globalisasi pada masyarakat dunia. Di antaranya; (a) setiap harinya bisa kita saksikan ribuan manusia terbang di seluruh dunia, (b) hadirnya media komunikasi dan informasi seperti internet, telepon, televisi, dan radio yang tidak mengenal batas teritorial tertentu, (c) perusahaan-perusahaan multinasional dan kecil mulai kehilangan identitas kebangsaan dan secara bertahap mulai mengglobal, (d) semakin populernya bahasa Inggris sebagai bahasa komunikasi masyarakat dunia, dan (e) terbukanya layanan transaksi keuangan (valuta asing) selama 24jam di seluruh dunia.

Kecenderungan globalisasi ini telah melanda hampir semua aspek kehidupan, mulai dari ekonomi, teknologi, kebudayaan, pendidikan, hingga agama. Berikut akan dibahas secara singkat aspek-aspek berikut:

\section{Aspek Ekonomi}

John Naisbitt dan Patricia Aburdence menyatakan globalisasi ekonomi dalam tiga pernyataan; (a) kekuatan-kekuatan ekonomi dunia telah melintas batas ikatan-ikatan nasional, mengakibatkan pada demokrasi yang lebih, kebebasan yang lebih, kesempatan yang lebih, dan kesejahteraan yang lebih besar, (b) pada ekonomi global, pertimbangan-pertimbangan ekonomi hampir selalu berkaitan dengan pertimbangan-pertimbangan politis, dan (c) pada ekonomi global, presiden, perdana menteri, dan parlemen akan semakin tidak berguna. ${ }^{5}$ Secara jelas, adanya globalisasi ekonomi ini ditandai oleh semangat perdagangan bebas (free trade) lintas negara di dunia. Untuk hal ini, umumnya telah dibuat kesepakatan-kesepakatan antarnegara yang menuju arah tersebut. Di Eropa, misalnya, sejak tahun 1992 telah diberlakukan mata uang euro yang menandai mulainya era pasar bebas antar-12 negara Eropa. Demikian juga di Amerika dan Kanada yang telah memulai hal yang sama pada tahun 1988. 


\section{Aspek Teknologi}

Kehidupan manusia di masa sekarang maupun yang akan datang, banyak bergantung kepada teknologi. Era cyber banyak mengubah tatanan dan struktur kehidupaan umat manusia. Hadirnya media internet dewasa ini telah banyak memunculkan sisi-sisi kehidupan, yang barangkali tidak pernah ada dalam bayangan orang pada satu abad yang lalu. Kemajuan teknologi membawa perubahan yang drastis pada sektor industri dan sistem ekonomi. Marquardt dan Engel menyatakan tentang globalisasi teknologi sebagai berikut:

"Inthenew millennium, everyindustrial country will havethis same hit parade' of technology-microelectronics, biotechnology, newmaterials (ceramics, plastics, and composites), telecommunications, robotics and machines tools, and computers and software. This result will be global headto-head competition in everymajormarket".

\section{Aspek Budaya}

Kebudayaan merupakan cara hidup keseharian manusia dalam sebuah masyarakat atau organisasi. Pada zaman dulu, manusia dalam sebuah komunitas masyarakat bisa berperang karena mempertahankan kebudayaan hidup mereka yang dicemari oleh pihak lain. Saat ini, pola pikir dan cara hidup manusia sudah banyak berubah dan menuju globalisasi. Paloma Picacco menyatakan: "the world is becoming more and more cosmopolitan, and we are all influencing each other"? Ada beberapa kategori kebudayaan di dunia ini yang telah berada dalam bentuk globalisasi, yaitu makanan (food), pakaian (fashion), film, musik dan hiburan, penerbitan, siaran televisi, dan bahasa.

\section{Aspek Pendidikan}

Di negara-negara maju seperti Amerika Serikat, Kanada, Inggris, dan Australia, memang sengaja secara eksplisit memiliki bidang studi 'global education'. Isu pokok studi ini adalah memperkenalkan aspek budaya bangsa-bangsa lain di dunia pada siswa mereka. Di lihat dari tujuan pendidikan nasional mereka, negara maju memang siap menghadapi gerakan globalisasi. Misalnya, Amerika Serikat dalam dokumen America 200: An Education Strategy, terdapat enam tujuan pendidikan nasional Amerika Serikat. Salah satunya bahwa Amerika serikat memang ingin memiliki pengaruh secara global. Untuk mencapai cita-cita itu, pendidikan Nasional diformulasikan sebagai: US student will be first in the world in science and mathematicsachievement. ${ }^{8}$

Globalisasi dalam dunia pendidikan ini juga bisa dilihat dari banyaknya pelajar-pelajar yang menekuni pendidikan secara lintas negara. Belum lagi dengan adanya sistem 'perkuliahan jarak jauh' yang memungkinkan sebuah universitas membuka cabangnya di negara lain.

\section{Aspek Agama}

Persoalan agama merupakan sesuatu yang tidak bisa diabaikan dalam globalisasi karena semenjak masa renaissance peran agama secara bertahap mulai dikebiri sehingga menjadi tuntutan pada setiap pemuka agama untuk bisa merelevankan ajaran agamanya agar tetap bisa eksis dalam tatanan baru dunia global. Kehidupan beragama yang eksklusif dan tidak toleran, barangkali sudah saatnya dikubur dalam-dalam, dan masing-masing agama, dan bersiap untuk menawarkan sesuatu yang berarti dalam pembentukan tatanan kehidupan global.

Pengaruh globalisasi, tentunya tidak bisa dibatasi hanya pada persoalan yang telah diangkat di atas, tetapi lebih dari itu, langkah pembahasannya merambah hampir semua segi kehidupan. Sebagai umat beragama (Islam), kita harus merespon problem yang muncul sebagai konsekuensi logis dari kehadiran globalisasi dengan mendasarkan pada universalitas ajaran Islam. Oleh karenanya, pemahaman bahwa Islam merupakan ajaran global adalah suatu keharusan yang tidak bisa di tawartawar lagi.

\section{MEMAKNAI ISLAM}




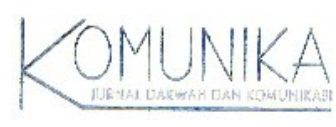

Dilihat dari sudut bahasa, kata "Islam" berarti kedamaian (peace), kesucian (purity), kepatuhan (submission), dan ketaatan (obedience) 9 Kata "salam" yang ma’rifat dengan "al" (al-salam) merupakan salah satu dari al-asma' al-husna, nama yang dikaitkan dengan Allah, dan oleh karenanya, memiliki kesucian. Oleh karena merupakan istilah yang suci, maka perdamaian merupakan sesuatu yang sudah selayaknya untuk disucikan. Menurut Hanafi, karena kesucian perdamaian inilah, manusia tidak diperkenankan menggunakan istilah "salam' untuk nama diri, kecuali dikaitkan dengan "Abdul" pada awalnya sehingga menjadi Abdul Salam. Hal ini memberikan implikasi bahwa seorang muslim itu adalah hamba dari perdamaian, yang berkewajiban mengimplementasikan nama suci tersebut ke dalam kehidupan dan mengarahkan perbuatannya untuk perdamaian.10 Dalam pengertian agama Islam, Islam berarti kepatuhan terhadap kehendak dan kemauan Allah SWT, serta taat kepada hukum dan aturan-Nya, atau sebagaimana yang diungkapkan oleh Abdurrahman anNahlawi, Islam adalah aturan Allah yang sempurna yang mencakup berbagai bidang kehidupan, juga mengatur hubungan manusia dengan Allah SWT, dengan sesamanya, dan alam semesta, atas dasar ketundukan dan ketaatan kepada Allah dan Rasul-Nya."

Pengertian Islam menurut bahasa dengan pengertian menurut istilah, yaitu hanya dengan kepatuhan dan ketaatan kepada kehendak Allah dan tunduk kepada hukum dan aturan-Nya. Seseorang dapat mencapai kedamaian yang sesungguhnya dan memperoleh kesucian yang abadi. Sebagaimana firman Allah dalam surat al-Baqarah 112:

"(Tidak demikian) bahkan barang siapa yang menyerahkan diri (aslama wajhahu) kepada Allah, sedang dia berbuat kebajikan, maka baginya pahala di sisi Tuhannya dan tidakada kekhawatiran terhadap mereka dantidak(pula)mereka bersedih hati.”2

Sebagai satu-satunya agama Allah, Islam merupakan manhaj al-hayat atau way of life, acuan dan kerangka tata nilai kehidupan. Memahami Islam sebagai way of life harus terkait satu bagian dengan bagian lainnya. Sebagai satu tata nilai, Islam tidaklah hanya sebagai landasan etis dan moral saja, tetapi ajarannya sangat bersifat operasional dan aplikatif dalam segala segi kehidupan manusia. Ketinggian karakteristik al-Quran, yang merupakan sumber nilai utama dari nilai dan norma ajaran Islam karena bisa dipraktikkan dalam kehidupan. Ia tidak berisikan tumpukan teori yang memadati pikiran belaka. Ajaran Islam bukan saja mendorong umatnya untuk senantiasa mencari dan mengembangkan berbagai ilmu pengetahuan, tetapi juga mendorong untuk mengamalkan ilmu itu di tengah-tengah kehidupan.

Ajaran Islam tidak pula mengenal pemisahan antara kehidupan duniawi dan kehidupan ukhrawi. Kehidupan dunia merupakan sarana ibadah kepada Allah SWT dalam rangka mendapatkan kebahagiaan yang abadi di akhirat kelak. Hal ini sebagaimana Firman Allah:

"Maka carilah pada apa yang dianugerahkan Allah kepadamu (kebahagiaan) negeri akhirat, dan janganlah kamu melupakan bagianmu dari (kenikmatan) duniawi, dan berbuat baiklah (kepada orang lain) sebagaimana Allah telah berbuat baik kepadamu, dan janganlah kamu berbuat kerusakan di(muka) bumi. SesungguhnyaAllahtidakmenyukai orang-orangyang berbuat kerusakan"(al-Qashash: 77).

Pada prinsipnya, Islam berisikan tata nilai yang menyeluruh, yang membuat manusia dijamin dapat mencapai tingkat kedudukan yang tinggi dalam pandangan Allah SWT, dengan memanfaatkan semua potensi yang dimilikinya yang merupakan anugerah dari Allah SWT. Tata nilai tersebut bisa dijadikan alternatif acuan di zaman globalisasi ini karena sifatnya yang universal dan fleksibel terhadap perubahan dan perkembangan.

\section{ISLAM SEBAGAI AJARAN GLOBAL (UNIVERSAL)}

Globalisme atau universalisme Islam merupakan sebuah pemahaman yang berangkat dari fakta tekstual historis bahwa risalah Islam ditujukan untuk semua umat, segenap ras dan bangsa, serta untuk semua lapisan masyarakat. Ia bukan risalah untuk bangsa tertentu yang beranggapan bahwa dialah bangsa terpilih, dan karenanya semua manusia harus tunduk kepadanya. Meskipun pada awalnya berada di dalam tubuh suatu bangsa, sekelompok bangsa atau hanya sekelompok individu, ia adalah satu dalam arti, bahwa ia meliputi seluruh manusia. Oleh karenanya, berbicara secara Islam, tidak bisa ada tata sosial Arab atau Turki, Iran atau Pakistan ataupun Malaysia, melainkan satu, yaitu tata sosial Islam, walaupun tata sosial bermula dari negeri atau kelompok tertentu. ${ }^{13}$ Risalah Islam adalah Hidayah Allah untuk segenap manusia dan rahmat-Nya untuk semua hamba-Nya. Manifesto ini termaktub abadi dalam firman-Nya: 


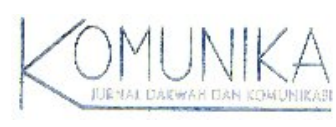

"Dantidak kamiutus engkau(Muhammad), kecuali sebagai rahmahbagiseluruh alam”"4 atau:

"Katakanlah (Muhammad): "Hai manusia sesungguhnya aku adalah utusan Allah kepadamu semua agar ia menjadi juru peringatan bagi seru sekalianalam"15

atau dalam ayat:

"Maha suci Allah yang telah menurunkan al-Furqan (al-Quraan) kepada hamba-Nya, agar ia menjadi pemberi peringatan kepada seluruh alam”.16

Universalisme Islam menampakkan diri dalam berbagai manifestasi penting, dan yang terbaik dalam ajaran-ajarannya. ${ }^{17}$ Ajaran-ajaran Islam yang mencakup aspek akidah, syariah, dan akhlak (yang seringkali disempitkan oleh sebagian masyarakat menjadi hanya kesusilaan dan sikap hidup), menampakkan perhatiannya yang sangat besar terhadap persoalan utama kemanusiaan. Hal ini dapat dilihat dari enam tujuan umum syariah, yaitu menjamin keselamatan agama, badan, akal, keturunan, harta, dan kehormatan. Selain itu, risalah Islam juga menampilkan nilai-nilai kemasyarakatan (social values) yang luhur, yang bisa dikatakan sebagai tujuan dasar syariah, yaitu keadilan, ukhuwah, tafakkul, kebebasan, dan kehormatan. ${ }^{18}$ Berikut berbagai manifestasi penting Universalisme Islam.

\section{Kosmopolitanisme Kebudayaan}

Universalisme dapat dilihat pada kosmopolitanisme kebudayaan yang ditawarkan, tempat ia tetap merespon dengan baik, dan mengakui eksistensi budaya-budaya lokal, yang pada kondisi-kondisi tertentu, malah terkadang dipandang sebagai bagian dari ajaran Islam. Islam menempatkan manusia pada posisi yang sejajar dalam tatanan peradaban global, sebagai 'anak-anak' Adam yang telah tercerai-berai, apa dan bagaimanapun dia, tidak akan mengubah status sebagai turunan Adam.

Pemahaman semacam itu, selain merupakan pancaran makna Islam itu sendiri, pandangan tentang kesatuan kenabian (wahdat al-nabawiyah; the unity of prophet) berdasarkan makna Islam itu, serta konsisten dengan semangat prinsip-prinsip itu semua, kosmopolitanisme 'budaya' Islam juga mendapat pengesahan langsung dari kitab suci seperti pengesahan berdasarkan konsep-konsep kesatuan kemanusiaan (wahdat al-insaniyah; the unity of humanity) yang merupakan kelanjutan konsep kemahaesaan Tuhan (wahdaniyat atau tauhid; the unity of God). Kesatuan asasi umat manusia dan kemanusiaan itu ditegaskan dalam firman-firman:

"Umat manusia itu tidak lain adalah umat yang tunggal, tapi kemudian mereka berselisih (sesama mereka), jika seandainya tidak ada keputusan (kalimah) yang telah terdahulu dari Tuhanmu, maka tentulah segala perkara yang mereka perselisihkan itu akan diselesaikan (sekarang juga).".

\section{Atau pada ayat:}

"Umat manusia itu dulunya adalah umat yang tunggal, kemudian Allah mengutus para nabi untuk membawa kabar gembira dan memberi peringatan dan bersama para nabi itu diturunkannya kitab suci dengan membawa kebenaran, agar kitab suci itu dapat memberi keputusan tentang hal-hal yangmerekaperselisihkan..." ${ }^{20}$

Para pengikut Nabi Muhammad Saw. dïngatkan untuk selalu menyadari sepenuhnya kesatuan kemanusiaan, dan dijadikan dasar mereka membentuk pandangan budaya kosmopolit, yaitu sebuah pola budaya yang konsep-konsep dasarnya meliputi, dan diambil dari seluruh budaya umat Islam. ${ }^{21}$ Refleksi dari manifestasi kosmopolitanisme Islam bisa dilacak dalam etalase sejarah kebudayaan Islam sejak zaman Rasulullah, baik dalam format nonmaterial seperti konsep-konsep pemikiran, maupun yang material seperti seni arsitektur bangunan. Pada masa awal Islam, Rasulullah berkhutbah hanya dinaungi sebuah pelepah kurma, kemudian tatkala kaum muslimin bertambah banyak, dipanggillah seorang tukang kayu Romawi. Ia membuat untuk Nabi sebuah mimbar dengan tiga tingkatan yang dipakai untuk khutbah Jum'at dan munasabah-munasabah lainnya. Dalam peristiwa lain, ketika perang Ahzab, Rasul menerima saran Salman al-Farisy untuk membuat parit (khandaq) di sekitar Madinah sebagai salah satu metode pertahanan ala Persi, dan Rasul melaksanakan saran tersebut dan mengaguminya. Para sahabat juga meniru manajemen administrasi dan keuangan dari Persi, Romawi, dan lainnya. Mereka tidak keberatan dengan hal tersebut selama menciptakan kemashlahatan dan tidak bertentangan dengan nash. Sistem 


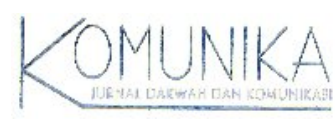

manajemen tersebut digunakan dalam perpajakan dengan mengadopsi dari Persi, sedangkan sistem perkantoran (diwan) mengadopsi Romawi. ${ }^{22}$

Pengaruh filsafat Yunani dan budayanya (hellenisme) pada umumnya dalam sejarah perkembangan pemikiran Islam bukan merupakan hal yang baru. Tampak sekali dalam metode ushul fiqh yang sering dipergunakan oleh para ulama kita, banyak menggunakan logika Aristotelian. Terlebih dunia filsafat yang tidak akan pernah bisa dicabut dari akar peradaban Yunani. Bahkan, bisa dianggap bahwa kejayaan yang dicapai oleh Islam, merupakan hasil kecerdikan' para cendekiawan muslim dalam mengadopsi pemikiran Yunani, yang kemudian secara bijak mengaplikasikan dalam bentuknya yang khas di dunia Islam.

Walaupun Islam sebagai agama bersifat universal yang menembus batas-batas bangsa, ras, dan peradaban, tetapi tak bisa dinafikan bahwa unsur Arab mempunyai beberapa keistimewaan dalam Islam. Ada hubungan kuat yang mengisyaratkan ketiadaan kontradiksi antara Islam sebagai agama dengan unsur Arab. Menurut Dr. Imarah, hal ini bisa dilihat dari beberapa hal:

Pertama, Islam diturunkan kepada Muhammad bin Abdullah, seorang Arab. Demikian juga mukjizat terbesar agama ini (al-Quran), didatangkan dengan bahasa Arab yang jelas (al-Mubin), yang dengan ketinggian sastranya dapat mengungguli para sastrawan Arab sepanjang sejarah. Oleh karena itu, memahami dan menguasai al-Qư’an sangat sulit dengan bahasa apapun selain bahasa Arab. Implikasinya, Islam menuntut pemeluknya jika ingin menyelami dan mendalami makna kandungan al-Qư'an, maka hendaknya 'mengarabkan' diri.

Kedua, dalam menyiarkan dakwah Islam yang universal, bangsa Arab berada di garda depan, dengan pimpinan kearaban Nabi dan al-Qur'an. Kebangkitan realita Arab dari segi "sebab turunnya wahyu" dengan peran sebagai penafsir terhadap al-Qur'an dan lokasi dimulainya dakwah di Jazirah Arab sebagai garda depan dalam dakwah.

Ketiga, jika agama-agama terdahulu memiliki karakteristik yang sesuai dengan konsep Islam lokal, kondisional, dan temporal, maka Islam mengandung dasar-dasar ajaran yang berlaku untuk semua tempat dan semua zaman. Ajaran Islam berlaku pada semua situasi dan kondisi, serta mengakui pengelompokkan alamiah manusia ke dalam keluarga, suku, dan bangsa sebagai pengaturan yang dikehendaki Tuhan. Akan tetapi, Islam menolak setiap ultimisasi dari pengelompokan tersebut sebagai kriteria final dari kebaikan dan kejahatan. Di atas semua manusia, baik individu maupun kelompok, berdirilah ketentuan hukum sebagai kenyataan bagi kebaikan dan kejahatan.23 Contoh keuniversalan ajaran Islam, ditinjau dari zaman, adalah konsep musyawarah yang disebut dalam al-Qur'an. Ayat tersebut mengatakan "Bermusyawarahlah dengan mereka". Penjelasan tentang musyawarah tidak ada dalam al-Quran. Oleh karenanya, pada setiap sistem pemerintahan, penerapan ajaran ini bisa jadi tidak sama. ${ }^{24}$

\section{Perkembangan Ilmu Pengetahuan}

Keuniversalan Islam juga digambarkan oleh ilmu yang dikembangkan. Ulama zaman klasik, yaitu zaman antara abad ke8 dan ke-13 M, mereka tidak hanya menguasai di bidang agama, tetapi juga merambah kepada keilmuan 'sekuler' (sains), seperti kedokteran, matematika, astronomi, kimia, optika, geografi, dan sebagainya.

Nama-nama yang termasyhur dalam ilmu kedokteran ialah al-Thabari (abad IX), al-Razi (865-925), Ibnu Sina (9801037 M.), dan Ibnu Rusyd (1126-1198 M.). Selain Ibn Rusyd di Andalus atau Spanyol, Islam dikenal juga al-Zahrawi sebagai ahli bedah pada abad ke-19 M. Dari keturunan Ibn Zur muncul dokter perempuan.

Dalam bidang matematika dikenal al-Hawarizmi (750-850 M), bapak ilmu aljabar. Kata algoritme dalam matematika berasal dari al-Khawarizme ini. Nama-nama lain adalah 'Umar al-Khayyam, al-Thusi, al-Kindi, al-Mahani dan al-Quhi yang mengarang buku dengan judul Tambahan terhadap Buku Archimedes. Angka Arab dibawa ke Italia dan Afrika pada permulaan abad ke tiga belas, maka angka yang sekarang dipakai di Eropa dikenal dengan angka Arab, untuk membedakannya dengan angka Romawi. Angka nol adalah ciptaan ahli matematika Arab yang dalam bahasa Arab disebut shifr. Kata ini menjadi cipher dalam bahasa Inggris. 


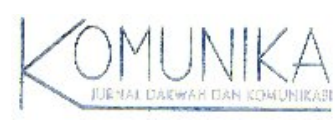

Astronom Islam pertama adalah al-Farizi (w.777). Astronom-astronom lain adalah al-Farghani, al-Battani, al-Thusi, 'Umar al-Khayyam, dan beberapa kota di Spanyol Islam. Al-Battani, misalnya, melakukan koreksi terhadap karya-karya Ptolomeus, sedangkan kalenderyang dibuat 'Umar al-Khayyam dipandang lebih tepat dari kalender yang dibuat Gregorius.

Bapak ilmu kimia Islam ialah Ibn Hayyan (721-815 M). Ia mengarang buku mengenai konsentrasi air raksa. Nama besar di bidang ilmu pengetahuan optika adalah Ibnu Haytsam, yang dalam bukunya menentang teori Euclid dan Ptolomeus, bahwa benda dapat dilihat karena mata mengirim cahaya ke dalam benda itu. Teori Ibn Haytsam adalah sebaliknya, benda dapat dilihat karena benda mengirim cahaya ke mata. Sementara dalam Geografi, nama al-Khawarizmi juga pernah memberikan sumbangsih terhadap ilmu pengetahuan. Ia mengarang buku berjudul Surat al-Ardh (Peta Bumi), yang di dalamnya ia jelaskan peta dunia Islam pada zamannya. Al-Masudi mengelilingi dunia sampai ke Nusantara, dan demikian juga Ibn Bathutah.

Dalam ilmu pengetahuan alam, ulama-ulama Islam menulis tentang ilmu hewan, ilmu tumbuh-tumbuhan, antropologi, geografi, geologi, dan lain-lain. Nama-nama yang masyhur dalam bidang ini adalah al-Jahiz, Ibn sina, Ibnu Miskawih, alQuzwuni, Ikhwan al-Shafa, dan lain-lain. Teori evolusi tujuh abad sebelum Darwin telah dikemukakan oleh al-Jahiz, Ibn Miskawih dan Ikhwan al-Shafa. Menurut teori ini, alam mineral lebih dahulu ada, kemudian alam tumbuh-tumbuhan, lalu alam hewan dan terakhir alam manusia. Evolusi dari alam mineral ke alam tumbuh-tumbuhan terjadi melalui merjan, dari tumbuh-tumbuhan ke alam hewan melalui pohon kurma, dan dari hewan ke alam manusia melalui kera.

Begitu pula ilmuwan lainnya, seperti Ali al-Hasan Ibnu Haitam (965-1038) yang menemukan ilmu pasti, Abu Raihan Ibnu Ahmad al-Baruni (973-1051 M) dalam bidang ilmu falak, Muhammad al-Syarif al-Idrisi (1100-1166M) dalam bidang ilmu bumi alam, abu Zakariyya Yahya Ibnu Awwam (w.1185 M) dalam bidang pertanian, Abu Usman Amr Ibnu Bahr al-Jahiz (776-869) dalam bidang ilmu hewan.5

Universitas-universitas didirikan di Dunia Islam. Ke sanalah mahasiswa-mahasiswa dari Prancis, Inggris, dan lain-lain datang menuntut ilmu yang dikembangkan ulama-ulama Islam itu. Di antara mahasiswa itu adalah Roger Bacon dan Michael Scott. Buku-buku karangan ulama Islam diterjemahkan ke dalam Bahasa Latin, dan Toledo menjadi pusat penerjemahan. Penerjemah-penerjemah terkenal adalah Adelard Bath, Gerard Cremona, dan lain-lain. Pada penutup abad ke-13 M, filsafat dan sains yang dikembangkan ulama Islam itu telah berpindah ke Eropa. Akibatnya, renaisans pun timbul di benua itu. Dari sini bisa dilihat bahwa peran orang Islam sangat besar sehingga orang-orang Eropa memiliki peradaban. Merekalah yang menjadi guru orang Eropa selama enam ratus tahun. ${ }^{26}$

\section{Totalitas Tata Sosial}

Universalitas Islam juga dapat dilihat pada tata sosial Islam yang totalis, dalam arti, bahwa Islam relevan dengan setiap bidang kegiatan hidup manusia. Dasar tata sosial ini adalah kehendak Tuhan yang pasti relevan dengan setiap makhluk karena Tuhan telah memberikan kepada manusia konstitusi, struktur, dan fungsi. ${ }^{7}$ Dalam dimensi fisik, personal, sosial dan spiritualnya, manusia memiliki konstitusi anugerah Tuhan yang wajib dipenuhinya. Tidak satu pun dari kegiatannya yang lepas dari penentuan Tuhan, dan dia tidak bisa memproyeksikan suatu tujuan dalam upayanya di bidang apapun, yang tidak termasuk dalam kategori wä̈b hingga haram dalam syari’ah. Di samping itu, suatu tanda mentalitas yang telah berkembang dan sempurna adalah bidang yang diperbolehkan ( $m u b a h$ ) paling banyak berisi hal-hal yang dibutuhkan dalam Islam.

Ketentuan hukum di atas dapat direlevankan dengan era global, yang menganalisis, menyimpulkan, memperluas, dan mengekstrapolasikan hukum-hukum tersebut, merupakan hal yang niscaya. Jika tidak demikian, maka sifat universal dari kehendak Tuhan dengan semua masalah, yang menjadi landasan utama syariah akan goyah. Tata sosial yang paling baik sebagai konsekuensi dari kebenaran tersebut adalah tata sosial yang mengatur sebanyak mungkin aktivitas manusia, dan pemerintah yang paling baik, adalah yang paling banyak mengatur. Begitu pula, sebagaimana pernyataan Hasan al-Banna sebagaimana dikutip oleh al-Faruqi bahwa kehendak Tuhan selalu relevan dengan segala peristiwa. ${ }^{28}$

Totalisme tata sosial Islam tidak hanya menyangkut aktivitas-aktivitas manusia dan tujuan-tujuannya di masa mereka saja. Ia mencakup seluruh aktivitas di setiap masa dan tempat, dan juga semua manusia yang merupakan subjek dari aktivitas- 
aktivitas tersebut. Sementara itu, Islam menganggap bahwa semua umat Islam termasuk dalam program pelaksanaan hukum. Islam juga menganggap orang-orang bukan Islam sebagai anggota yang memiliki kemampuan dan harus diperhatikan. Dengan demikian, tidak ada akhir bagi tata sosial sepanjang kehidupan dan aktivitas di dunia ini juga belum berakhir. Tugas yang harus dijalankan adalah campur tangan semua pihak, baik manusia sebagai individu, komunitas masyarakat, bahkan benda sebagai pelaksana-pelaksana kehendak Illahi.29

\section{Islam sebagai Acuan Tata Nilai yang Dinamis}

Islam sebagai ajaran agama yang universal mampu menjadi tata nilai sebagai acuan bagi kehidupan yang serba berkembang dan dinamis, sekaligus menunjukan keagungan, keutuhan, dan keunikannya. Keunikan Islam dalam tata nilai tersebut dapat dilihat pada:

Pertama, syariat Islam adalah tata nilai, aturan, dan norma ciptaan Allah SWT, yang mengetahui segala sesuatu yang dibutuhkan oleh manusia. Tata nilai tersebut dibuat sesuai dengan sendi umum kemanusiaan, baik secara individu maupun sosial kemasyarakatan. Tidak mungkin terjadi pertentangan antara ajaran Islam yang bersumberkan wahyu Allah SWT dan fitrah manusia sebagai makhluk-Nya..$^{30}$

Kedua, seluruh tata nilai dalam ajaran Islam dimaksudkan untuk kesejahteraan agar manusia terpelihara agamanya, dirinya, akalnya, kehormatannya, dan harta bendanya. Ajaran Islam tidak pernah menyuruh, kecuali kepada hal-hal yang munkar, tidak pernah melarang kecuali yang mungkar, tidak pernah menghalalkan kecuali yang baik, dan tidak pernah mengharamkan kecuali yang buruk ${ }^{31}$ Al-Islam minhaj at-taghyir, Islam adalah agama yang menghendaki perubahan, mengeluarkan manusia dari keadaan zhulumat menuju kehidupan yang penuh dengan mur. Ada tiga macam zhulm, yaitu ketidaktahuan tentang syari’at, pelanggaran atas syari’at Allah, dan penindasan. Islam diturunkan untuk membebaskan manusia dari kehidupan yang penuh dengan kemaksiatan menuju ketaatan, dari kebodohan tentang syariat menuju pemahaman tentang halal, haram, baik, buruk, apa yang sepatutnya dilakukan, dan apa yang tidak. Juga dari kehidupan yang penuh dengan belenggu dan penindasan, menuju kehidupan yang penuh dengan kebebasan, tempat manusia dihargai sebagai manusia yang mempunyai derajat dan kedudukan yang sama di hadapan Allah, yang membedakannya hanyalah ketakwaan kepada-Nya.

Ketiga, syumuliyah, yaitu mencakup semua segi kehidupan manusia. Ia adalah ajaran yang berkaitan dengan sistem keyakinan, aturan, moral, pemikiran, ilmu pengetahuan, nilai-nilai kemanusiaan, hukum, sistem keluarga, serta hubungan antarmanusia, yang saling berhubungan dan tidak terpisahkan satu dengan yang lainnya. Unsur-unsurnya disusun sedemikian rupa, mencakup seluruh segi kehidupan, melengkapi segala kebutuhan, dan melindungi segala kegiatan. Dalam lingkup ini, prinsip tauhid merupakan prinsip yang pertama agama Islam, dan prinsip segala yang Islami. Allah itu tunggal secara mutlak dan tertinggi dan secara metafisis dan aksiologis. Dia adalah Sang Pencipta, yang dengan perintah-Nya, segala sesuatu dan peristiwa terjadi. Ia kemudian menjabarkan dari prinsip tauhid ini ke kesatuan alam semesta, kesatuan kebenaran, kesatuan pengetahuan, kesatuan hidup, dan kesatuan umat manusia..$^{32}$

Keempat, tata nilai Islam itu tampil dalam bentuk prinsip-prinsip umum menyeluruh yang melahirkan gerak maju. Sejarah telah menunjukkan kepeloporan umat Islam dalam berbagai bidang kehidupan yang sejalan dengan peningkatan kualitas kemanusiaan itu sendiri. Penguasaan peradaban yang tinggi dilandasi dengan akidah, persamaan, keadilan, persaudaraan, serta nilai-nilai tinggi lainnya.

\section{MEMOSISIKAN ISLAM DALAM GLOBALISASI}

Dari pemaparan keuniversalitas Islam di atas, dapat dipahami, bahwa secara prinsip, Islam sangatlah relevan sebagai ajaran global. Persoalannya kemudian, bagaimana memosisikan Islam dalam percaturan globalisasi? Dalam hal ini, dapat digarisbawahi bahwa Islam sebagai ajaran global yang memiliki ajaran universal merupakan bagian yang tidak bisa dipisahkan dari globalisasi. Menyikapi problema globalisasi, maka prinsip-prinsip ajaran Islam yang universal bisa dijadikan dasar berpijak bagi umat Islam. Di sinilah, pemahaman yang tepat terhadap nash menjadi syarat yang harus dipenuhi. Islam pada 


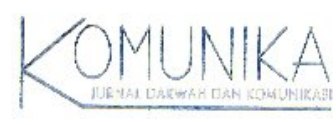

prinsipnya satu secara aqidah, tetapi pada bidang-bidang yang lainnya, boleh jadi berbeda, atau malah bertentangan. Namun demikian, semua itu secara keseluruhan tetap berada dalam naungan Islam.

Dalam menyikapi globalisasi ekonomi yang merupakan bagian dari realita saat ini, Islam sebagai sebuah ajaran moralitas memberikan batasan-batasan agar tidak terjadi eksploitasi antara manusia yang satu dengan yang lain. Islam menghendaki persamaan (musawwah) atas prinsip harta tidak hanya beredar di kelompok-kelompok tertentu saja. Perilaku ekonomi Islam bertujuan untuk menyejahteraan semua pihak. Prinsip utama dari ekonomi Islam di era global adalah (1) tauhid: keesaan dan kedaulatan Allah. Konsepsi ini menuntut adanya kepatuhan terhadap aturan-aturan yang telah ditetapkan tanpa syarat. Dalam konsepsi ini, eksistensi manusia dipersatukan dalam ketaatan kepada Allah, yang akan berimplikasi pada aktivitas ekonomi, yaitu tidak ada diskriminasi;33 (2) keadilan: hal ini penting karena keadilan menjadi suatu titik tolak dalam membangun kesejahteraan hidup. Dari sini akan muncul kedinamisan dalam kehidupan berbangsa dan bernegara, (3) tanggung jawab: dalam prinsip ekonomi Islam, setiap pelaku ekonomi harus bertanggung jawab, baik dari sisi ekses ataupun aktivitasnya kepada diri sendiri dan masyarakat atau pun bangsa. Demikian juga tidak dibolehkan terjadi kerusakan ekologi sebagai akibat manfaat teknologi yang berlebihan. Prinsip ekonomi Islam ini muncul dalam rangka melakukan kritik dan solusi atas banyaknya kekurangan yang terdapat dalam ekonomi kapitalis.

Pada aspek budaya, Islam memiliki kebudayaan sendiri yang kosmopolit, tetapi Islam juga mengakui eksistensi kebudayaan lokal. Kosmopolitanisme budaya Islam dibentuk oleh budaya lokal, tempat Islam itu tersebar. Sebagai bukti konkret, kita mengenal Islam Jawa, Islam Madura, Islam Iran dan lain sebagainya, yang meskipun secara kultur tidak sama, tetapi tetap dalam kesatuan Islam. Islam pada waktu berasimilasi yang membentuk tatanan kebudayaan baru yang khas.

Pada aspek pendidikan, tawaran yang hendak disampaikan oleh Islam adalah pendidikan yang integralistik. Berbeda dengan pendidikan umum dewasa ini, Islam tidak menghendaki dualisme pendidikan. Pendidikan selain diperuntukkan untuk mencapai 'kebahagiaan' dunia, juga seyogyanya diwarnai dengan nilai-nilai transendensi kepada Sang Maha Pendidik, yaitu Allah SWT. Pendidikan seyogyanya mengutamakan kepentingan moralitas sebagai bagian yang esensial dalam tata kehidupan manusi. Namun demikian, tidak berarti antipati terhadap modernisme yang merupakan produk Barat. Oleh karena itu, pendidikan merupakan sistem bagi pengembangan iptek yang berangkat dari ajaran al-Quran dan Sunnah, sebagai pembaharuan pemikiran yang dapat merespon tantangan zaman tanpa mengabaikan aspek teologis dogmatis, dan sebagai sarana untuk menumbuhkembangkan sikap dan mental manusia yang benar-benar bertakwa kepada Tuhan tanpa mengenal batas akhir.34

Pada aspek teknologi, Islam menghendaki teknologi yang tepat guna, dalam arti, tidak hanya memberikan kemudahan dan kenyamanan, tetapi juga tetap menempatkan manusia sebagai subjek penentu. Teknologi juga tidak boleh mengeksploitasi alam secara membabi buta sehingga merusak ekologi yang ada. Globalisasi yang berangkat dari penggunaan teknologi yang merusak ekologi inilah yang dilarang dalam Islam.

\section{KESIMPULAN}

Sebagai akhir dari tulisan ini, penulis akan mengemukakan beberapa kesimpulan sebagai berikut:

1. Globalisasi sebagai bagian dari proses sejarah merupakan kenyataan yang tidak bisa dipungkiri, yang memberikan pengaruh yang sangat luar biasa dalam perubahan tatanan kehidupan masyarakat dunia;

2. Sebagai bagian dari dunia, Islam merupakan agama global, yang memiliki universalitas ajaran yang bisa dipergunakan untuk mewarnai kehidupan masyarakat global. Oleh karenanya, perhatian yang mendalam terhadap ajaran-ajaran Islam yang universal, merupakan suatu yang niscaya agar Islam bisa memberi suatu konstribusi yang berartibagi peradaban global;

3. Universalitas ajaran Islam tidak berarti mematikan potensi budaya lokal, tetapi eksistensi budaya lokal tetap diakui. Peradaban dan kebudayaan Islam dibangun atas kombinasi nilai ketakwaan, persamaan, dan kreativitas dari dalam diri Islam yang universal dengan akulturasi timbal balik dari budaya lokal; dan 


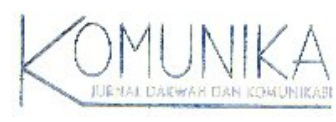

4. Universalitas Islam dapat berperan dalam menyikapi problem globalisasi dan menjadi pijakan bagi umat Islam, baik dalam bidang ekonomi, pendidikan, kebudayaan, dan Ilmu pengetahuan dan teknologi.

\section{ENDNOTE}

1 Ungkapan ini dikemukakan kembali oleh Antony Giddens sebagai respon melihat kondisi nill masyarakat dunia yang semakin tidak jelas masa depannya sebagai akibat dari globalisasi yang telah mengubah banyak sendi-sendi kehidupan masyarakat dunia. Anthony Giddens, "Runaway World. Bagaimana Globalisasi merombak Kehidupan Kita", dalam www.gramedia.com

${ }_{2}^{2}$ Poedjawijatna, Pembimbing ke Arah Alam Filsafat (Jakarta: PT. Pembangunan, 1980), hal. 20.

${ }^{3}$ Adlnan Benan Omer, "Nasionalisme Haprak Menunggu Mat”, dalam Berita Keadilan, edisi 30 Juni 2001.

${ }^{4}$ Alvin dan heidi Toffler, War and Anti-War: Survival at Dawn of the 21st Century (New York:Wamer Book, 1993), hal. 318-319.

5 John Naisbitt dan Patricia Aburdence, Megatrends 2000 (New York: Avon Book, 1990), hal. 1.

${ }^{6}$ Michael Marquardt dan Dean W Engel, Global Human Resource Development (New Jersey: Prentice- Hall, Inc, 1995), hal. 295.

${ }^{7}$ Paloma Picasso dalam Megatrends, OP.Cit. hal. 116.

${ }^{8}$ Khusus untuk bahasa gaul global, umumnya yang sangat dominan dipergunakan adalah bahasa Inggris. Saat ini lebih dari 100 negara menjadikan bahasa Inggris sebagai bahasa pertama atau kedua.

${ }^{9}$ Didin Hafidhuddin, Dakwah Aktual (Jakarta: Gema Insani, 1998), hal. 15.

${ }^{10}$ Hassan Hanafi, Agama, Kekerasan dan Islam Kontemporer, terj. Ahmad Najib (Yogyakarta: Jendela, 2002), hal. 126.

${ }^{11}$ Didin Hafidhudin, Dakwah Aktual.

${ }^{12}$ Q.S. al-Baqarah: 112.

${ }^{13}$ Ismaill Raji al-Fanuqi, Tauhid, terj. Rahmani Astuti (Bandung: Pustaka, 1988), hal. 110.

${ }^{14}$ Q.S al-Anbiya: 107.

${ }^{15}$ Q.S. al-A'raf: 158.

${ }^{16}$ Q.S. al-Furqan: 1.

17 "Universalisme Islam dan Kosmopolitanisme Peradaban Islam" oleh Abdurrahman Wahid dalam Budhy Munawar Rahman (ed), Kontekstualisasi Doktin Islam dalam Sejarah (Jakarta: Yayasan Paramadina, 1994), hal. 515.

${ }^{18}$ Yusuf Qardhawi, Madkhal li al-Dirasat al-Islamiyyah (Beinut: Dar al-Syuruq, 1993), hal. 61.

${ }^{19}$ Q.S. Yunus: 19.

${ }^{20}$ Q.S. al-Baqarah: 213.

${ }^{21}$ Nurcholish Madjid, ISlam, Doktrin dan Peradaban (Jakarta: Paramadina, 1992), hal. 422.

${ }^{2}$ Yusuf al-Qardhawi, Madkahi. hal. 253.

${ }_{23}^{23}$ Muhammad Imarah, Al-Islam wa al-Urubah (al-Haihal al-Mashriyah al-Ammah lil Kitab, 1996), hal. 11-12.

${ }^{24}$ Hanun Nasution, Islam Rasional (Bandung: Mizan, 1998), hal. 34.

${ }^{25}$ Sirajuddin Zar, Filsafat Islam, Filosof dan Filsafatnya (Jakarta: PT Raja Grafindo Persada,2004), hal. 30.

${ }^{26}$ Harun Nasution, Islam Rasional, hal. 35.

${ }^{27}$ Q.S. al-Furqan, 25: 2. Sementara universalisme Islam tampak jelas dalam kenyataan bahwa ketentuan-ketentuan Islam ditujukan pada semua manusia, semata-mata karena mereka adalah manusia, totalismenya juga tampak jelas dalam kenyataan bahwa manakala ada bidang perilaku manusia yang belum ada aturannya dalam hukum, Islam mewajibkan kaum Muslimin untuk menentukannya. Kaum Muslimin wajib mengusahakan penerapan wahyu pada masalah sehari-hari dan soal-soal yang mereka hadapi. litihad adalah tugas universal bagi semua Muslim, karena Tuhan telah menyatakannya demikian dalam al-Qur'an (Q.S al-Ar'am, 6: 38).

${ }^{28}$ Ismaiil Raji, Tauhid, hal. 112.

${ }_{29}$ Tiadalah Kami alpakan sesuatupun dalam al-Kitab, kemudian kepada Tuhanlah mereka akan dibangkitkan (Q.S, al-An'am, 6:38).

30 "Maka hadapkanlah wajahmu dengan lurus kepada (agama) Allah; (tetaplah atas) fitrah Allah yang telah menciptakan manusia menurut fitrah itu. Tidak ada perubahan pada fitrah Allah. (Itulah) agama yang lurus, tetapi kebanyakan manusia tidak mengetahui." (Q.S, al-Rum: 30).

${ }^{31}$ al-A'raf. 157.

${ }^{32}$ Didin Hafiduddin, Dakwah Aktual, hal. 22.

${ }_{33}$ Seyyed Nawab Nagwi, Etika dan IImu Ekonomi, suatu Sintesa Islami, terj. Husin Anas (Bandung: Mizan, 1993), hal. 50-51.

${ }^{34}$ H.A.R. Tllaar, Beberapa Agende Reformasi Pendidikan Nasional dalam Perspekdif Abad 21 (Magelang: Tera Indonesia, 1998), hal. 31. 


\section{DAFTAR PUSTAKA}

Faruqi, al, Ismail Raji. 1988. Tauhid. Terj. Rahmani Astuti. Bandung: Pustaka.

Giddens, Anthony. "Runaway World: Bagaimana Globalisasi merombak Kehidupan Kita". dalam www.gramedia.com Hafidhuddin, Didin. 1998. Dakwah Aktual. Jakarta: Gema Insani.

Hanafi, Hassan. 2002. Agama, Kekerasan, dan Islam Kontemporer. Tej. Ahmad Najib. Yogyakarta: Jendela. Imarah, Muhammad.1996. Al-Islam wa al-Urubah. al-Haihal al-Mashriyyah al-'Ammah lil Kitab.

Madjid, Nurcholish. 1992. Islam, Doktrin, dan Peradaban. Jakarta: Paramadina.

Marquardt, Michael dan Dean W Engel. 1995. Global Human Resource Development. New Jersey: Prentice-Hall. Inc. Nagwi, Seyed Nawab. 1993. Etika dan IImu Ekonomi, suatu Sintesa Islami. tej. Husin Anas. Bandung: Mizan.

Naisbitt, John dan Patricia Aburdence. 1990. Megatrends 2000. New York: Avon Book.

Nasution, Harun. 1998. Islam Rasional. Bandung: Mizan.

Omer, Adlnan Benan. 2001. "Nasionalisme Haprak Menunggu Mat”, dalam Berita Keadilan, edisi Juni 2001.

Poedjawijatna. 1980. Pembimbing ke Arah Alam Filsafat. Jakarta: PT. Pembangunan.

Qardhawi, Yusuf. 1993. Madkhal li al-Dirasat al-Islamiyyah. Beinut: Dar al-Syuruq.

Rahman, Budhy Munawar (ed). 1994. Kontekstualisasi Doktrin Islam dalam Sejarah. Jakarta: Yayasan Paramadina.

Tilaar, HAR. 1998. Beberapa Agende Reformasi Pendidikan Nasional dalam Perspektif Abad 21. Magelang: Tera Indonesia.

Toffler, Alvin dan Heidi Toffler. 1993. Warand Anti-War. Survival at Dawn of the 21st Century. New York: Wamer Book.

Zar, Sirajuddin Zar. 2004. Filsafat Islam, Filosof dan Filsafatnya. Jakarta: PT Raja Grafindo Persada. 